\title{
Lived Experiences of Educators Engaged in Continuing Professional Development in the New Normal: Insights from Seven Countries
}

\author{
Glen P. Cortezano1, Rolando V. Maningas², Alberto D. Yazon ${ }^{3}$, Lerma P. Buenvinida4, \\ Consorcia S. Tan ${ }^{5}$, Victoria E. Tamban 6 \\ 1, 2, 3, 4, 5, 6Laguna State Polytechnic University-Los Banos Campus, Philippines
}

\begin{abstract}
This study focused on exploring and capturing the essence and meaning of the lived experiences of educators engaged in continuing professional development in the new normal. The study followed a qualitative research design and used the transcendental phenomenological processes. Based on the testimonies gathered from the participants from seven different countries- Philippines, USA, Panama, Peru, Pakistan, Nigeria, and Morocco they revealed that as a result of the Continuing Professional Development during the pandemic, they had manifested adaptability and innovation to meet the demands of the current situation. With the forced transition from face-to-face interaction to remote learning, they have tried their best to maintain a balance of digital and life skills. Participants also engaged in CPD in order to achieve creativity and resourcefulness to deliver and meet students' quality learning amidst pandemics. They are also considered as blessings and great opportunities for the connection and collaboration established with educators around the world during this time of Covid19. They also achieved a passion for an ever-learning mindset and satisfaction through CPD. Participants expressed that the mindfulness and wellbeing of teachers should be set as priorities for their engagement to CPD in the new normal. The researcher recommends that the policymakers review and revisit their program for CPD training of the teachers during this period. Heads of the education sectors may also benchmark the CPD Training plan of this study and conduct needs analysis to provide the most appropriate training for the teachers based on their needs, skills, and interests.
\end{abstract}

Keywords: Continuing, Development, Educators, New Normal, Professional

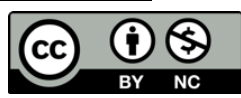

This is an open access article under the CC-BY-NC license.

\section{INTRODUCTION}

Teachers' professional development is described as "activities that improve teachers' skills, knowledge, expertise, and other teacher characteristics" (OECD, 2009, p.49). According to Levin (2014), professional learning is a more apt concept for professional development these days because it is "ongoing, always intense, and often centered on enhancing student learning."

Due to the current situation, the COVID-19 pandemic, which is considered the major global pandemic for the last 100 years, teachers' professional development has been greatly affected. The pandemic has brought extraordinary challenges and has affected the education sectors all over the world. For more than a year now, each country is still implementing plans and procedures on how to contain the virus as the infections are still continually rising. Since January 30, 2020, the Philippines has faced a critical situation due to COVID-19 Pandemic. The Higher Education Institutions, along with the Department of Education's (DepEd) primordial concern, was to avoid and limit the risks of the infection of the academic community. The implementation of the community quarantine led to the postponement of the conduct of classes and other face-to-face activities. The challenge now is how to continue teaching and learning beyond face-to-face instruction.

Corresponding author

Glen.cortezano@lspu.edu.ph; rvmaningas@lspu.edu.ph; albertyazon@lspu.edu.ph

DOI: https://doi.org/10.31098/ijmesh.v4i2.670

Research Synergy Foundation 
International Journal of Management, Entrepreneurship, Social Science and Humanities (IJMESH), Vol. 4 (2), $129-145$ Lived Experiences of Educators Engaged in Continuing Professional Development in the New Normal: Insights from Seven Countries

Glen P. Cortezano; Rolando V. Maningas; Alberto D. Yazon; Lerma P. Buenvinida; Consorcia S. Tan; Victoria E. Tamban

Educational institutions in most parts of the world have physically closed with students and faculty forced to shift from traditional to distance learning and working from home. With this drastic change, the education sector faces an unprecedented challenging situation, especially the students and faculty members. People's lives and routines have dramatically changed as they continue this ongoing battle with the COVID-19 pandemic. However, it is fair to say that despite the educational disruption, the education sector has not been fully jolted due to digital convergence and the online education revolution. The year 2020 marks the history in education. The forced transition of many traditional classes and activities to an online digital learning environment may result in the longer-term adoption of remote working and learning (Qadir 2020).

Globally, teacher education programs are designed to provide educators with the certification and competencies required in their professional careers (Rao, 2004). Institutional management intentionally creates in-service training opportunities to ensure quality teaching and faculty retention (Ali, 2008). Guskey (2002, p. 381) emphasizes the importance of professional development, saying, "high-quality professional development is a central component of virtually every modern plan for improving education." Similarly, according to Seyoum (2011), educational changes will only succeed if "teachers are equipped with subject matter expertise and an evidence-and-standards-based range of pedagogical skills" (p.381). Given the key importance of professional development programs for the successful realization of any educational transformation, school staff's quality of learning activities is a major issue in both policy discussion and educational research (Wilson \& Berne, 1999).

As the world begins to relax some of the strict measures that have been in place, the only certain thing is that the 'new normal' will not be the same as before.

For this reason, the researcher saw the big challenge that lies in what new skills do educators need to support the students and how they can continue to develop as professionals in the current situation.

With the shared practices and experiences of educators from different countries such as the Philippines, USA, Panama, Nigeria, Pakistan, Morocco, and Peru leading professional development, the academic leaders in any education sector can gain various strategies on how to provide continuing professional development for teachers during this new normal. In order to explore and understand the lived experiences of educators engaged in continuing professional development in the new normal, the researcher formulated the following research questions:

1. How do the educators describe their experiences as regards the challenges encountered on continuing professional development in the new normal?

2. How do educators perceive continuing professional development in the new normal?

3. What themes emerge from the testimonies shared by the educators on continuing professional development in the new normal?

4. Based on the findings and reflections, what continuing professional development model for educators can be provided?

\section{LITERATURE REVIEW}

As Covid 19 Pandemic may result in the longer-term adoption of the new normal, teachers and students face the challenge of sustaining and maintaining the teaching and learning process. The teachers on the onset of a pandemic have been trying their best to equip themselves with the necessary skills and knowledge needed in the new setup for the delivery of instructions. Teachers have been engaged in online training, webinars, online courses, self-directed learning activities to keep themselves updated. These online engagements of teachers became their avenue for continuing professional development in the new normal. 
International Journal of Management, Entrepreneurship, Social Science and Humanities (IJMESH), Vol. 4 (2), $129-145$

Lived Experiences of Educators Engaged in Continuing Professional Development in the New Normal: Insights from Seven Countries

Glen P. Cortezano; Rolando V. Maningas; Alberto D. Yazon; Lerma P. Buenvinida; Consorcia S. Tan; Victoria E. Tamban

\section{Continuing Professional Development in the Philippines}

Continuing Professional Development is strongly promoted in many countries in the developed world. The Philippines, among the ASEAN member states (AMS), is unique in implementing its continuing professional development (CPD) policy among its professionals. It is the only AMS country that requires CPD compliance for the renewal of the Professional Identification Card of its professionals (David 2020 Professional Regulation Commission, Republic of the Philippines).

Resolution No. 1240 Series of 2020 Section 3, Article I of Republic Act (R.A) No. 10912 or the CPD Act of 2016 defines Continuing Professional Development or CPD as the inculcation of advanced knowledge, skills, and ethical values in a post-licensure specialization or an inter-or multidisciplinary field of study, for assimilation into professional practice, self-directed research and/or lifelong learning. However, due to the Corona Virus Disease 2019 (COVID-19) crisis, the President issued Proclamation No. 922 (s.2020) declaring a State of Public Health Emergency throughout the Philippines and Proclamation No. 929 (s. 2020) declaring a State of Calamity throughout the Philippines. CPD Providers cancelled their planned program offerings, including conventions, conferences, and other types of mass gatherings, which are important ways for practitioners to keep up with their CPD requirements and may not be available during the COVID-19 crisis. This resolution suggests other ways of CPD compliance, such as self-directed learning activities, informal and professional work experience, and online training activities, which may also be availed of by professionals.

The mandatory CPD in the Philippines was introduced through the Republic Act (RA) 10912 or the CPD Act of 2016. The CPD law's main goal is to encourage, upgrade, and strengthen the skills of Filipino professionals in the country. (2). The CPD law requires all regulated professions, including teachers and other professionals, to obtain CPD credit units as a mandatory requirement for the renewal of the Professional Identification Card (PIC). There is consensus among scholars that professional development is linked with ongoing education or continual learning. R.A. No. 8981, or the PRC Modernization Act of 2000, empowers the Commission to administer, enact, and execute regulatory policies in the Philippines. The State recognizes the important role of professionals in nation-building and promotes the sustained development of a reservoir of professionals whose competence has been determined by honest and credible licensure examinations and whose standards of professional service and practice are internationally recognized and congruent, according to Section 2 of this Act, "Statement of Policy." The Professional Regulation Commission Resolution No, 1032 Series of 2017, Implementing Rules and Regulations IRR of Republic Act no. 10912, known as the Continuing Professional Development (CPD) Act of 2016.

To make higher education institutions responsive to the changing nature of education among them, public scrutiny of the quality of teaching and increasing demands for quality graduates by professional bodies and employers, the Commission on Higher Education (CHED) issued Memorandum no. 41, series of 1998

"Continuing Professional Development for Teaching Staff in Higher Education Institutions, by the pertinent provisions of Republic Act No. 7722, otherwise known as the "Higher Education Act of 1994". The Commission recommends that institutions of higher learning adopt appropriate strategies for 
International Journal of Management, Entrepreneurship, Social Science and Humanities (IJMESH), Vol. 4 (2), $129-145$ Lived Experiences of Educators Engaged in Continuing Professional Development in the New Normal: Insights from Seven Countries

Glen P. Cortezano; Rolando V. Maningas; Alberto D. Yazon; Lerma P. Buenvinida; Consorcia S. Tan; Victoria E. Tamban

their teaching staff as to promote a culture of continuous professional learning; All HEIs, public and private, are enjoined to start with the professional needs and assessments of their teachers. This information can be made as springboards for attractive and interesting continuing professional development (CPD) programs that can help tackle the challenge of quality education.

Aside from the aforementioned advantages of CPD, Filipino teachers have been engaged to CPD even with or without CPD credits. They realized the need for continuing professional development to keep themselves updated with the demands of the current learning and teaching modalities. Teachers have been creating webinars and online courses as part of their professional learning and development.

\section{Continuing Professional Development in the USA}

In the USA, associations and professionals are also involved in preparing and implementing CPE. These services are focused on topics that the practice has defined as essential to the profession's well-being and practitioners' progress or as helpful in achieving desired results for the profession's client systems. Government departments are also significant supporters and distributors of CPE, with a number of services available. A professionally structured curriculum centered around definite goals, such as seminars, institutes, courses, and lectures, is a more popular type of CPE. These processes, taken together, account for just a limited portion of the lifelong learning that practitioners engage in. They are typically brief and based on a general refresher of technical competencies, a summary of a new topic or set of procedures, or an attempt to implement a new method, experience, or set of practice protocols. In most professions, distance education has had a significant influence, but its effectiveness has varied depending on how the discipline is conducted. Computer-assisted and web-based CPE has evolved more quickly in technical and scientific areas than in teaching and social care, where the practice environment is less conducive to the use of technology and technological solutions.

\section{Continuing Professional Development in Morocco}

Professional learning for teachers and school leaders is a top priority of the National Charter for Education and Training. Inspectors of pedagogy play a vital part in Morocco's educational system. They plan teacher professional development programs, colloquia, and workshops, among other things, and supervise teachers to enhance teaching and learning within the country's 12 provincial academies for education and training. Globalization and free trade negotiations have undeniably been a forwardmoving driver in recent debates regarding the relevance of continuing education and career growth in Morocco, according to Hasi 2013. The latter has recently been designated as a national priority, requiring Morocco to reconsider the goals of its training framework and introduce a number of policies and processes (Hassi, 2011). Morocco has two essential and complementary structural structures that support employee preparation and growth. Organizations may use one or more of these methods at the same time. Intersectoral Advice Associations (GIAC, Groupements interprofessionel d'aide au Conseil) operate across sectors to encourage the value of workforce training and to offer professional and financial support to businesses during the processes of training requirements review and plan planning.

To establish continuing education practices within Moroccan, here are the recommendations 1. a national framework for school-based Continuing Professional Development (CPD) should be developed. This approach is designed to assist teachers in identifying and gaining access to highquality professional development programs that will enable them to reach their maximum potential. 
International Journal of Management, Entrepreneurship, Social Science and Humanities (IJMESH), Vol. 4 (2), $129-145$ Lived Experiences of Educators Engaged in Continuing Professional Development in the New Normal: Insights from Seven Countries

Glen P. Cortezano; Rolando V. Maningas; Alberto D. Yazon; Lerma P. Buenvinida; Consorcia S. Tan; Victoria E. Tamban

2. all the elements that make up the national Framework for CPD should be fully and adequately described in a booklet. This booklet should describe key aspects of the CPD Framework, highlight how teachers can identify their CPD needs, outline the sort of activities that can be recognized as CDP, and answer some of the teachers' frequently asked questions about CPD. 3. A national CPD advisory board should be set up, the mission of which is to establish collaborative communities, collect and record successful CPD practices, develop and make the national framework for school-based framework for CPD available. 4. CPD should be part and parcel of teachers' pre-service training input. 5. All teachers should have an entitlement to research training to develop their role as critical users of continuing professional development-oriented research. 6. All schools should be responsible for participating in a relevant continuing professional development-oriented research partnership for appropriate periods.

\section{Continuing Professional Development in Panama}

The Panamanian government aims to establish a bilingual community to achieve accelerated economic development and improve citizens' quality of life. As a first step towards achieving this goal, the Government established the Panama Bilingue Project to raise national English language teaching standards and increase the number of English teachers working in schools. The credential initiative, which is co-led by MEDUCA and Cambridge English, seeks to transform national teacher preparation strategies by incorporating innovative approaches and methodologies and developing a long-term professional development policy. As the first stage in this process, they undertook an analysis of English proficiency and teaching knowledge among a sample of teachers from across Panama. From the teachers surveyed, 78 were selected to train as 'expert instructors and were enrolled onto their Train the Trainer course, an internationally renowned course designed to develop the skills required to plan and deliver teacher training programs. Expert instructors went on to run training courses for 500 teachers throughout Panama after finishing the Train the Trainer course.

The courses included 200 hours of face-to-face and online instruction, with outstanding learners receiving a Cambridge English CELT-P or CELT-S degree. Both CELT-P and CELT-S are internationally recognized qualifications that focus on developing the practical skills required to teach English effectively. Cambridge English is continuing to support the work and vision of MEDUCA and is now establishing an annual training program for English teachers, with further opportunities to achieve established professional development qualifications.

\section{Continuing Professional Development in Nigeria}

The training of teachers in Nigeria began with the introduction of formal education by the missionaries, Babatunde (1999). The focus then shifted to assisting the persons in fulfilling their duties as Bible catechists, interpreters, and students. In 1985, Formalized teacher professional education, however, began with the establishment of a training school in Abeokuta by the church missionary society. Teacher professional education programs for secondary schools were introduced during the time that Nigerians moved towards independence based on the recommendation of the Ashby commission (1956). One of such was the advanced teacher's colleges, now known as colleges of education. They are supervised by the National Certificate of Education (NCE), which is awarded to their graduates. According to Oyenike, Adesoji, and Adebayo (2009) in Miefa (2004), there are 72 such colleges in Nigeria. 
International Journal of Management, Entrepreneurship, Social Science and Humanities (IJMESH), Vol. 4 (2), $129-145$ Lived Experiences of Educators Engaged in Continuing Professional Development in the New Normal: Insights from Seven Countries

Glen P. Cortezano; Rolando V. Maningas; Alberto D. Yazon; Lerma P. Buenvinida; Consorcia S. Tan; Victoria E. Tamban

To uplift the standard requirements of under-qualified teachers as earlier experienced led to the establishment of the Teachers' Registration Council of Nigeria (TRCN) in 1993, which has the responsibility to determine the standards of knowledge and skills to be attained by persons seeking to become registered as teachers (TRCN, Decree 31,1993) • Compulsory registration of all professional teachers; - Make the Nigerian credential of education (NCE) the minimum compulsory certification for teachers; and $\bullet$ Encourage in-service teachers to participate in a mandatory continuing professional education program.

The inability to provide a variety of general knowledge training and facilities as needed for all the programs has become a major barrier to effective teacher training and, consequently, the full implementation of the Universal Basic Education (UBE). Now that the UBE is in operation, Nigeria is starting to have expanded resources for players in the primary education sectors. This aligns with the global demand for "education for all" (EFA), which mandates that all people have access to basic education.

\section{Continuing Professional Development in Pakistan}

In Pakistan, pre-service training is not a prerequisite for university faculty positions. According to Saleem, Masrur, and Afzal (2014), there are no agreed-upon instructional competencies for university teachers either at a national or provincial level in Pakistan. There is still no scheme in place for university faculty to receive in-service instruction. Aslam (2011) correctly points out, universities in Pakistan lack an adequate career development program because they lack a human resource department capable of developing such policies. According to LID's key goals, "to orient teachers in a particular topic and teaching strategies; to assist teachers in learning knowledge, skills, and techniques about successful teaching; and to motivate teaching staff in universities and degree-awarding institutions with the new tools, pedagogical skills, and techniques about their disciplines" (HEC, 2017).

Despite all these developments regarding the professional development of faculty, university teachers' participation in CPD activities is not mandatory. It is observed that limited research has been conducted in Pakistan to look into the issues related to the professional development of university teachers. Researches such as (e.g., Gujjar et al., 2010; Hussain, 2004; Sultana, 2010) have concentrated on schoolteachers' teaching and professional development. Sultana (2007) sought to evaluate the need for the professional advancement of college teachers as one of the few forms of a study performed on faculty development in higher education institutions. In his doctoral research, Ali (2008) analyzed the need and proposed faculty development programs for universities of Pakistan. In their study, Saleem, Masrur, and Afzal (2014) investigated the effect of professional development on enhancing the knowledge level of university teachers in Pakistan. Aslam (2011) also looked at the problems and obstacles that public universities in Pakistan face when it comes to career growth.

\section{Continuing Professional Development in Peru}

In Peru, teacher reform began in 2012 with the approval of the new teaching career law. It originally was called the "Peru Teacher Plan" and had four components: the teaching career, implementation of an in-service training program, a system of incentives and stimuli, and development of strategies for teacher participation in the design and evaluation of education policies. 
International Journal of Management, Entrepreneurship, Social Science and Humanities (IJMESH), Vol. 4 (2), $129-145$ Lived Experiences of Educators Engaged in Continuing Professional Development in the New Normal: Insights from Seven Countries

Glen P. Cortezano; Rolando V. Maningas; Alberto D. Yazon; Lerma P. Buenvinida; Consorcia S. Tan; Victoria E. Tamban

In October 2013, there was a change of minister, and some aspects of the reform were subsequently modified. It was given a new name, the "Integral Policy for Teacher Development," and reduced to three components. The teaching profession component was retained, but the engagement component was removed, and the other two were increased. Teacher training included in-service training and initial education of teachers. The package of incentives was reorganized into more comprehensive teacher welfare schemes. The objectives were not changed substantively. The general sense was preserved, and the reform's key goal is to enable teachers to contribute to their professional learning while also encouraging creativity and the development of pedagogical skills. Legal and scientific tools support the reform's adoption. The teacher evaluation scheme and professional welfare policies are the technical tools.

The purpose of the study was to explore the experiences of the local and international educators on providing and facilitating continuing professional development in the new normal. This study would help the academic leaders to benchmark, plan and design the most appropriate and timely professional development for teachers, which is limited to the current situation. This study would also help them to reflect on the importance and relevance of technology integration as the need for continued learning increases for teachers to develop new skills and instructional practices that incorporate technology in meaningful ways.

This research would contribute to the leaders of the Higher Education Institutions, as they can generate new ideas and various strategies on how to provide continuous professional development for teachers during this new normal.

This would also help establish international collaborations and linkages, which would open opportunities for research and other professional development activities and projects for the educators.

This study focused on listening to the voices of the educators on their experiences on continuing professional development in the new normal. From knowing and understanding the lived experiences of the educators on providing CPD, the researcher crafted a Continuing Professional Development in the New Normal Training Plan. This plan served as a guide that the institutional leaders could use, academic heads, deans and associate deans, and Human Resources Management Office in designing and planning for learning and training opportunities for continuing professional development for educators.

As referred to in this study, the continuing professional development consists of online training and courses, webinars, online collaboration, and self-directed learning engaged by educators. Thus, this transcendental phenomenological study focused on understanding the lived experiences of educators leading and facilitating professional development in the new normal.

Capturing the essence of how these educators pursue continuing professional development amidst the pandemic was one of the main goals of this study. This study also explored how and how the educators used to conduct professional development despite the disruption.

\section{RESEARCH METHODS}


International Journal of Management, Entrepreneurship, Social Science and Humanities (IJMESH), Vol. 4 (2), $129-145$ Lived Experiences of Educators Engaged in Continuing Professional Development in the New Normal: Insights from Seven Countries

Glen P. Cortezano; Rolando V. Maningas; Alberto D. Yazon; Lerma P. Buenvinida; Consorcia S. Tan; Victoria E. Tamban

This research study focused on the lived experiences of the educators as their collective voices were heard through the research design. I collected data directly from the phenomena under study (Creswell, 2007). In this study, the phenomenon of educators engaged in continuing professional development in the new normal was explored. This qualitative research study included an in-depth analysis of the reported and shared experiences and testimonies of the participants. The following were the transcendental phenomenological process I considered and used in the treatment of qualitative data analysis.

1. I conducted synchronous individual interviews, asynchronous interviews through google form, and online Focus Group Discussion. All the online interviews were conducted via zoom with considerations to the participants' convenience and preferred time zone. After conducting the interview, I, myself, transcribed in verbatim all the shared experiences of the participants. I validated their interview responses from the results of their asynchronous interview. After the transcription, I conducted the second interview, the Focus Group Discussion, which aimed to follow up questions and explore more meanings to the participants' lived experiences. The transcriptions were then submitted to each participant for validation and confirmation of their shared testimonies.

2. I practiced setting aside my preconceived ideas on the phenomena (epoche). I listed and bracketed all my preconceived ideas, biases, and judgment. My personal experiences on the phenomenon were also revealed in the study. Throughout the process, I observed this approach so I could set aside my views of the phenomenon and focus on those views reported by the participants (Moustakas, 1994). This also helped me to remain fresh and new in observing the phenomenon.

3. The next step in this phenomenological study was a phenomenological reduction. I identified significant statements/horizons (horizonalization) in the database from participants and treated them with equal value. Specific statements in the transcript that described the participants' views and experiences related to his/her lived experiences on continuing professional development in the new normal were identified and numbered referred to as horizon.

4. After reviewing that all the horizons have met the requirements, I carefully examined all the invariant constituents and the interconnectedness of each quality. I remained practicing the phenomenological process of epoche to ensure that participants' descriptions and not my perception were considered throughout the data analysis. Then, I clustered these statements into meaning units and themes. From each of the significant statements of the participants, I generated 56 initial themes. Each of the initial themes was related to continuing professional development. Some of the themes were derived from the exact word of the participants. In this process, I used vivo coding. In vivo coding is a form of qualitative data analysis that emphasizes the actual spoken words of the participants. In vivo coding is championed by many for its usefulness in highlighting the voices of participants and for its reliance on the participants themselves for giving meaning to the data. (Manning 2017). I used this to make sure that the participants' actual experiences were reflected.

5. The next step was I examined these statements and initial themes and cluster them into sub-themes. In this manner, I derived 32 sub-themes from the initial themes.

6. After extracting sub-themes from initial themes, the next step was to check and review sub-themes and cluster them into final or main themes. In this step, all similar ideas were grouped. I maintained 
that the sub-themes and main themes reflected the actual lived experiences of the participants. The main themes were generated from the shared testimonies of the participants. To fully describe the phenomenon, a discovery of similar themes among different participants added to the rich, descriptive analysis of the phenomenon. Abstract concepts were not used as themes to ensure that I had derived the correct and appropriate themes from the participants' shared experiences and testimonies and become true in the essence of reflecting their actual experiences; the six generated themes were peerreviewed by three qualitative researchers and the participants themselves.

7. Next, I synthesized the themes into a description of the experiences of the individuals (textual and structural descriptions). Then, I wrote individual textural descriptions for each participant. Verbatim statements of the participants were lifted, and I prepared the narrative representing the participant's experience with the phenomenon.

8. Then, I constructed a composite textural description of the meanings and the essences of the experience. The composite textural description focused on a group description of the participants' lived experiences on continuing professional development in the new normal.

9. I also prepared individual structural descriptions for each participant. I integrated the structural qualities and themes into an individual structural description. I discussed the experiences, challenges, and perceptions on engaging in the continuing professional development in the new normal.

10. Then, I prepared the composite structural description. I strived to give meaning to the setting and context in which the phenomena were experienced (Moustakas, 1994). Using the themes, I wrote the structural description of the individual's experiences. Structural description discussed the meanings the individual attached to their lived experiences on continuing professional development in the new normal.

11. Then, I synthesized the composite textural and structural descriptions meanings and essences of the experiences. The composite description represented the meaning of the participants' experiences involved in the study. I presented the six main themes using a thematic framework as suggested by Kiurkow 2020. He mentioned that the researcher could present her themes in a way she prefers, like using tables, diagrams, or plain text.

\begin{tabular}{|c|c|c|c|c|c|}
\hline \multirow{3}{*}{$\begin{array}{l}\text { Researcher's } \\
\text { Epoche/Bra } \\
\text { cketing }\end{array}$} & \multicolumn{5}{|c|}{ Phenomenological Reduction } \\
\hline & $\begin{array}{l}\text { Horizonalizatio } \\
\mathrm{n} \text { (listing of } \\
\text { significant } \\
\text { statements) }\end{array}$ & $\begin{array}{l}\text { Invariant } \\
\text { Qualities and } \\
\text { Themes } \\
\text { (identifying } \\
\text { initial themes } \\
\text { from horizons) }\end{array}$ & $\begin{array}{l}\text { Clustering } \\
\text { Themes } \\
\text { (deriving sub- } \\
\text { themes to final } \\
\text { themes) }\end{array}$ & $\begin{array}{l}\text { Write-up of the } \\
\text { individual textural } \\
\text { description of } \\
\text { experiences }\end{array}$ & $\begin{array}{l}\text { Write up the } \\
\text { composite textural } \\
\text { description of } \\
\text { experiences }\end{array}$ \\
\hline & \multicolumn{2}{|c|}{$\begin{array}{c}\text { Imaginative } \\
\text { Variation }\end{array}$} & \multicolumn{3}{|c|}{ Essences } \\
\hline
\end{tabular}


International Journal of Management, Entrepreneurship, Social Science and Humanities (IJMESH), Vol. 4 (2), 129-145 Lived Experiences of Educators Engaged in Continuing Professional Development in the New Normal: Insights from Seven Countries

Glen P. Cortezano; Rolando V. Maningas; Alberto D. Yazon; Lerma P. Buenvinida; Consorcia S. Tan; Victoria E. Tamban

\begin{tabular}{l|l|c}
\hline Individual & Composite & Syntheses of Composite Textural- \\
Structural & Structural & Structural Description \\
Description & Description &
\end{tabular}

Figure 1: Transcendental Phenomenological Process (Moustakas 1994)

\section{FINDINGS AND DISCUSSION}

After collecting and analysing the shared experiences and testimonies from the participants from seven different countries, the following terms emerged from their testimonies:

The six main themes described the aspect of the actual experiences shared by the participants.

As part of the Continuing Professional Development during the pandemic, the participants have manifested adaptability and innovation to meet the demands of the current situation.

Participants perceived that the new normal was challenging and very different. They also felt that there were a lot of challenges due to the sudden shift, but due to their engagement with continuing professional development, they have learned to manage and adjust. The theme that emerged from the participants' testimonies implied that educators were trying their best to equip themselves with the skills even though it may be difficult for them. Their engagement to continuing professional development in the new normal helped them adjust to the situation. It also helped them use innovative tools and find activities and ways to deal with the teaching and learning in the new normal.

With the forced transition from face-to-face interaction to remote learning, the participants have tried their best to maintain a balance of digital skills and life skills.

Based on the testimonies of the participants and shared experiences during the interview, they have attended and facilitated various training and conferences on digital literacy skills, the use of tools and apps, and other online platforms. They also perceived that they also had attended other training which was not technology-related but focused on developing life skills. The second theme that emerged from these participants' narrative experiences proved that with the forced transition from face-to-face interaction to remote learning, the participants had tried their best to maintain a balance of digital skills and life skills.

They also believed that CPD training for teachers should not only focus on developing digital skills but should also consider other life skills. They perceived that teacher should be taught as well of managing tools and how to handle themselves in front of cameras. They believed that there should be a combination of teaching the tools and helping the teachers manage stress and anxiety in using the tools to help teachers become mentally, emotionally, and spiritually healthy.

Due to the current situation, participants engaged in CPD to achieve creativity and resourcefulness to deliver and meet students' quality learning.

They revealed that due to the current situation, they engaged in continuing professional development training to learn more tools and applications and enhanced their creativity and resourcefulness, which they can integrate into their classes and which they can use in facilitating professional development activities. They believed that this creativity and resourcefulness were also the shared skills during the 
International Journal of Management, Entrepreneurship, Social Science and Humanities (IJMESH), Vol. 4 (2), $129-145$ Lived Experiences of Educators Engaged in Continuing Professional Development in the New Normal: Insights from Seven Countries

Glen P. Cortezano; Rolando V. Maningas; Alberto D. Yazon; Lerma P. Buenvinida; Consorcia S. Tan; Victoria E. Tamban

conduct of their CPDs for teachers. They believed that they also had imparted these skills by giving them innovative ideas and providing them with different resources. All of the participants believed that most of the online engagement of teachers was in the form of webinars. They perceived that teachers have considered webinars as a form of professional development training that helped them improve their skills. As part of resourcefulness, there were participants who revealed that they were able to do more international collaboration on continuing professional development through a CovidRelief Grant which provided them financial assistance and helped them meet some of their CPD needs and somehow served as motivation and reward to pursue CPD amidst pandemic.

\section{Considered as blessings and a great opportunity during this time of pandemic was the connection and collaboration established.}

All of the participants believed that there was a lot of teachers' collaboration and creation of community practice and support groups that emerged during this time of crisis. They perceived that engagement and collaboration among educators were the results of the new normal. They considered connection and collaboration as a blessing and great opportunity during this time of the pandemic. All of them felt and realized the need to establish connections and rapport among educators across the globe. They believed that through interaction with other people, they also learned and improved themselves. All of the participants saw the significance of online collaboration and establishing a community of practice during this difficult situation.

What the pandemic has brought the participant was their passion for an ever-learning mindset and achieving satisfaction in their Continuing Professional Development.

All of the participants perceived that through continuing professional development, teachers were being helped and encouraged to learn to adapt to the new normal to perform better. They believed that teachers were integrating the skills they learned from their training into their classroom teaching. They also viewed that teachers used their training for their continuous self-improvement. All of the participants showed their desire for continuous learning and optimal growth and development. They perceived that CPDs helped them to grow personally and professionally. They felt that they should continue to learn and engage more in the different professional development training. All of them realized that they gained satisfaction in improving their skills and potentials through continuing professional development. They also believed that CPD also helped them develop their leadership skills to help other educators develop their skills and potentials. All of them expressed respect to those teachers who pursued professional development amidst the limitation brought by the Covid 19 Pandemic because of their passion for learning something new and for equipping themselves with necessary skills and competencies. Just like the seasoned teachers, they believed that they were trying their best to learn something new as if they were striving and aiming for professional development and for academic excellence too.

Maintaining and sustaining mindfulness and wellbeing was believed by the participants to be an important priority in their engagement to CPD in the new normal.

All of the participants believed that teacher's social and emotional learning self must not be taken for granted when conducting CPD. They also felt that teachers, aside from learning digital tools and enhancing digital skills, must also be supported with training that would help them grow emotionally, physically, and spiritually. All of the participants realized the need to empower teachers through selfcare and wellness. 
International Journal of Management, Entrepreneurship, Social Science and Humanities (IJMESH), Vol. 4 (2), $129-145$ Lived Experiences of Educators Engaged in Continuing Professional Development in the New Normal: Insights from Seven Countries

Glen P. Cortezano; Rolando V. Maningas; Alberto D. Yazon; Lerma P. Buenvinida; Consorcia S. Tan; Victoria E. Tamban

Aside from the theme that emerged, the testimonies of the participants also led to the development of a training plan on continuing professional development for educators in the new normal focused on the training on specific skills, competency, and aspects as suggested by the participants. This training will be concentrated on Teachers' Wellbeing and Mindfulness, Self-Directed Learning, Interactive Competence, and Digital Literacy Skills Training. This training plan was consisted of:

Area 1: CPD Overview and Process (COP). This area covers the introduction and overview of the CPD and the CPD Framework. It also includes the management of resources, goals, and objectives, and the target beneficiaries.

Area 2: CPD Needs Analysis Plan and CPD Cycle (CNAC). This area includes the pre-assessment of the training needs. It also discusses the need analysis part and the cycle of CPD, and the training flow and process.

Area 3: Priority Skills and Competencies Training Plan (PSC). This area includes the contents and instructional plan area. This covers the priority skills and competencies for training as well as the instructional design, methods, and strategies of the training plan. The following components of training are on Teachers' Wellbeing and Mindfulness, Self-Directed Learning, Interactive Competence, and Digital Literacy Skills Training.

Area 4: Monitoring, Evaluation, Sustainability, and Impact Area Plan (MESI). The last part of the training plan focuses on the monitoring and evaluating of the training itself and its outcome. This also includes the monitoring of the sustainability and impact of the training conducted among teachers in the new normal.

The majority of the participants expressed that their experiences in teaching in the new normal were challenging and different. However, their testimonies also revealed that despite challenges, their experiences were also fun, productive, and rewarding and that they learned to manage and adjust to the situation through their engagement with continuing professional development activities and training. As specified by Qadir 2020, the physical closure of most of the schools has forced both the students and teachers to shift from traditional to distance learning and working from home. This was an unprecedented challenging situation faced by the education sector especially affecting the students and faculty members. Due to Covid - 19 Pandemic, the lives and routines of people have drastically changed. However, the education sector has responded to this situation by looking for possible ways not to hamper the teaching and learning process. This Covid -19 Pandemic will mark the history of the forced conversion of many traditional classes and activities to the online learning environment. This may result in the longer-term adoption of remote working and learning. The participants themselves engaged in continuing professional development that supported them for ways and means to support teaching and training in the new normal.

The majority of the participants conveyed that the technical aspects like internet connection, internet cost, speed, and devices were the biggest challenge on their engagement to professional development in the new normal. However, they pointed out that teachers were showing their eagerness and willingness to learn despite the connection issues. Based on their shared testimonies, they dealt with the teachers having a different mindset, who struggled to trust and show willingness in engaging 
International Journal of Management, Entrepreneurship, Social Science and Humanities (IJMESH), Vol. 4 (2), $129-145$ Lived Experiences of Educators Engaged in Continuing Professional Development in the New Normal: Insights from Seven Countries

Glen P. Cortezano; Rolando V. Maningas; Alberto D. Yazon; Lerma P. Buenvinida; Consorcia S. Tan; Victoria E. Tamban

themselves with the continuing professional development in the new normal. The majority of them revealed the different mindsets of teachers in terms of engagement in continuing professional development in the new normal.

All of the participants have attended virtual professional development training and online courses. The testimonies of the participants implied that all of the participants were deeply and actively engaged in attending and facilitating professional development. Aside from looking for professional development opportunities, all of the participants have created different training and workshops for their professional growth and eventually shared as well with other educators.

One thing which was also common to all the participants was that they voluntarily and freely shared with other educators the knowledge, skills, and opportunities they had gained from continuing professional development.

All of the participants also emphasized that they were able to connect and collaborate with other different educators across the world through professional development activities. Based on the participants' experiences and testimonies on attending and facilitating professional development in the new normal, all of their engagements used and integrated digital technology tools and online platforms.

All the participants have manifested full engagement in professional development in terms of attending professional development training, webinars, and online courses and at the same time in organizing and creating various CPDs for teachers.

The findings above are supported by a recent international review that concludes that teachers must become 'active agents of their own professional growth' (Schleicher, 2012:73). This could be possible if teachers apply reflective practice Dewey (1993), which is the ability to reflect on one's actions to engage in the process of continuous learning. Reflection is mental processing that is used to fulfill a purpose to achieve some anticipated outcome. The ability to reflect on what, why, and how we do things and to adopt and develop our practice within lifelong learning makes up a good teacher. One way to do reflective practice is to engage in a Professional Learning Experience. These professional learning experiences can be a catalyst for reflecting on practice individually or with others. Professional learning experiences may be through joining a network, participating in professional learning programs, attending conferences which may constitute the continuing professional development programs.

In addition to the participants' full engagement in professional development, they also demonstrated excitement and eagerness to share ideas, knowledge, skills, and learning opportunities to educators not only in their local places but also to teachers around the world.

The majority of the participants revealed that they gained improvement of skills and potentials through professional development. The participants also described their engagement in professional development as having the opportunities to build connections with international communities. 
International Journal of Management, Entrepreneurship, Social Science and Humanities (IJMESH), Vol. 4 (2), $129-145$ Lived Experiences of Educators Engaged in Continuing Professional Development in the New Normal: Insights from Seven Countries

Glen P. Cortezano; Rolando V. Maningas; Alberto D. Yazon; Lerma P. Buenvinida; Consorcia S. Tan; Victoria E. Tamban

Notably, collaborative learning is most likely to be effective where attention is paid to developing trust, building on existing relationships and networks, recognizing respective roles and contributions, ensuring knowledge meets local needs and addressing competing priorities (Sebba, Kent \& Tregenza, 2012). In this study, collaboration with and among the educators was made possible through their online engagement in CPDs. Participants created these collaborations with educators to share the same experiences and learnings.

The participants' experiences in engaging to the different professional development for teachers in the new normal revealed these four subthemes: teachers' mindset in engaging to continuing professional development, use of different platforms for webinars, online courses and training for professional development, high demand for computers and internet connection and devices and established partnership and collaboration through online connections.

All of them mentioned the use of different platforms for webinars, online courses, and training for continuing professional development in the new normal like zoom, WhatsApp, Facebook, Webinars, YouTube, Virtual Classrooms, and Virtual Conferences Apps.

Participants revealed that the new and innovative approaches to professional development which they have encountered since the start of the pandemic were the use of different technology tools and applications in attending and facilitating webinars and training and online collaboration of teachers and creation of community network and support group.

In this study, collaboration with and among the educators was made possible through their online engagement in CPDs. Participants created these collaborations with educators to share the same experiences and learnings.

Aside from the use of different platforms and tools for professional development, the participants also viewed the online collaboration of teachers and the creation of a community network and support group as a new and innovative approach to the new normal. They pointed out that they were able to establish partnership and collaboration.

All of the participants narrated and shared their experiences on how they have established partnerships and collaborations. According to them, these partnerships and collaborations were made possible by the current situation. Through their online groups and social media channels like Facebook, YouTube Channel, WhatsApp, and even Podcast episodes, they were able to meet and collaborate with various educators around the world. Apart from meeting people, they also partnered with universities and schools across the globe and organized different training, webinars, and projects. There were participants who revealed that they were able to do more international collaboration on continuing professional development through a Covid-Relief Grant which provided them financial assistance and helped them meet some of their CPD needs and somehow served as motivation and reward to pursue $\mathrm{CPD}$ amidst pandemic.

With the strict social distancing measures and school closures in many countries, there has been an abrupt change to traditional modes of teaching and learning. As a result, UNESCO has recommended the adoption of distance learning programs and online educational applications designed to reach students remotely. In the same manner, approaches to teachers continuing professional development have shifted to online and blended learning modalities in the new normal. 
International Journal of Management, Entrepreneurship, Social Science and Humanities (IJMESH), Vol. 4 (2), $129-145$ Lived Experiences of Educators Engaged in Continuing Professional Development in the New Normal: Insights from Seven Countries

Glen P. Cortezano; Rolando V. Maningas; Alberto D. Yazon; Lerma P. Buenvinida; Consorcia S. Tan; Victoria E. Tamban

A range of digital webinars, online courses, and training has been available for free. Many professional leaders around the world have created webinars and training using different platforms. Using social media for professional learning is essential for developing and maintaining effective teaching.

Due to the sudden shift to online and remote learning to ensure sustainable, high quality, and flexible teaching and learning and to maintain continuing professional development, at the center of many of these learning strategies is the use of technology.

The majority of the participants stressed the digital literacy skills and digital citizenship of teachers. They also revealed that there were teachers who resisted change, teachers who did not even grasp the situation, and teachers being set up in the traditional setting. However, they also perceived that teachers were doing their best to adjust to the situation by engaging themselves with training and collaborating with other teachers.

All of these findings from the testimonies and narrated experiences of the participants are supported by the study on Teacher Digital capital which is also known as Teachers Professional Development. According to Seale (2013), digital cultural capital can be seen as individuals or groups investing effort and time into enhancing their technical knowledge and skills, employing various forms of learning, both formal and informal.

Teachers' digital capital consists of a combination of all their knowledge, skills, and attitudes, complemented by their personal and professional social networks or relationships, which influence their engagement with technology. Technological engagement is seen here as any situation teachers face in which they use or learn about technology. Based on the findings, it intensified the need to be integrated into the training plan on Continuing Professional Development for Educators in the new normal as the output of this study.

The participants' supposed training plans for Continuing Professional Development for educators in the new normal revealed that they would focus on training on digital literacy skills, technology integration and use of digital tools, and training on social and emotional learning, resiliency, and wellness of teachers. To enhance their skills in digital literacy and other topics, teachers are required to take professional development classes for continuous learning (Professional Development for Teachers, n.d.). There are many professional development topic options for teachers. However, teachers might not think digital literacy is an important skill since only several states have required digital literacy training based on state legislation (Digital Literacy, 2019).

All of them have seen the importance of integrating Social and Emotional Learning, Resiliency, and Mindfulness for Teachers. The outline of the training competencies based on the shared testimonies from the participants was: Training on Teachers' Wellbeing and Mindfulness, Self-Directed Learning, Interactive Competence, and Digital Literacy Skills Training.

\section{CONCLUSION}

The following conclusions were derived from the shared testimonies of the participants as well as from the reflection and analysis of the researcher. All of the participants' teaching experiences in the new normal were challenging. However, they found their experiences fun, productive and rewarding because of their engagement in continuing professional development.

They also believed that teachers' social and emotional learning aspects must not be taken for granted when conducting CPD. They also felt that teachers, aside from learning digital tools and enhancing digital skills, must also be supported with training that would help them grow emotionally, physically, 
International Journal of Management, Entrepreneurship, Social Science and Humanities (IJMESH), Vol. 4 (2), $129-145$ Lived Experiences of Educators Engaged in Continuing Professional Development in the New Normal: Insights from Seven Countries

Glen P. Cortezano; Rolando V. Maningas; Alberto D. Yazon; Lerma P. Buenvinida; Consorcia S. Tan; Victoria E. Tamban

and spiritually. All of the participants realized the need to empower teachers through self-care and wellness on teachers' collaboration during their engagement with continuing professional development in the new normal. They recognized the value of CPD in fostering a community of practice, sharing ideas, methods, and resources, getting to know other people from across the globe. All were made possible through teachers' connections and collaboration during CPD. The participants set a culture of professional learning where individual needs were met and considered, and opportunities for CPD were designed according to the respective needs of the teachers. Therefore, opportunities for reflection and research-based CPD in the new normal were provided and possible.

Since participants of this study came from seven different countries, this may lead to establishing international collaborations and linkages, which would open opportunities for research and extension and other professional development activities and projects for the educators.

Based on the findings of the study, the researcher has the following recommendations.

1. The educational institutions may strengthen their nationwide internet connectivity program, which may also benefit the teachers in order for them to facilitate remote teaching and learning as well as to pursue continuing professional development in the new normal.

2. The approved CPD Training Plan for the new normal may be proposed to CHED/DepEd for consideration and recommendation.

3. Heads of the school administration may consider conducting Professional Development Needs Analysis for teachers so they may develop the most appropriate training plan for teachers based on their skills, knowledge, interests, and needs.

4. Colleges and universities can also help in the continuing professional development of their graduates by aligning their curricula to the needs of companies and industries in local and global markets.

5. Future research collaboration on professional development with educators from other countries may be conducted. Teachers may have entitlement to research training to develop their role as critical users of continuing professional development-oriented research.

\section{REFERENCES}

Ali, S. (2008). Faculty Development Program for Universities of Pakistan: The need to develop a model. Lahore: University of Punjab.

Anonuevo, A. T. (2019). Successful Return Migration: A Study of Reintegration Experiences of Filipino Permanent Returnees.

Bacchus, F., \& Grove, A. (n.d.). Utility independence in a qualitative decision theory. KR.

Bandura, A. (1986). Social foundation of thought and action: A social cognitive theory. Englewood Cliffs: Prentice Hall.

Bandura, A., Freeman, W. H., \& Lightsey, R. (1999). Self-Efficacy: The Exercise of Control. Journal of Cognitive Psychotherapy, 13(2), 158-166. https://doi.org/10.1891/0889-8391.13.2.158

Bandura, A. (2001). Social Cognitive Theory: An Agentic Perspective. Annual Review of Psychology, 52(1), 1-26. https://doi.org/10.1146/annurev.psych.52.1.1

Becher, T. (1996). The learning professions. Studies in Higher Education, 21(1), 43-55.

Bourdieu, P. (1986). Forms of capital. In J. Richardson (Ed.), Handbook of theory of research for sociology of education (pp. 241-258). New York, NY: Greenwood Press.

Branscombe M. The New Stack; 2020. The network impact of the global COVID-19 pandemic.https://thenewstack.io/the-network-impact-of-the-global-covid-19-pandemic/ April 14, Retrieved June 6, 2020, from. [Google Scholar] [Ref list]

British Council. (2015). Technology for professional development: access, interest and opportunity for teachers of English in South Asia. New Delhi: British Council.

Burns, M. \& Lawrie, J. (Eds.). (2015). Where It's Needed Most: Quality Professional Development for All Teachers. New York: Inter-Agency Network for Education in Emergencies. 
International Journal of Management, Entrepreneurship, Social Science and Humanities (IJMESH), Vol. 4 (2), $129-145$

Lived Experiences of Educators Engaged in Continuing Professional Development in the New Normal: Insights from Seven Countries

Glen P. Cortezano; Rolando V. Maningas; Alberto D. Yazon; Lerma P. Buenvinida; Consorcia S. Tan; Victoria E. Tamban

Creswell, J. W. (2006). Educational research: Planning, conducting, and evaluating quantitative and qualitative research (2nd ed.). Upper Saddle River, NJ: Merrill Prentice-Hall.

Creswell, J.W. (2007). Qualitative inquiry and research design: Choosing among approaches (2nd ed.). Thousand Oaks, CA: Sage.

Clark, C. (2013). A PHENOMENOLOGICAL STUDY OF THE IMPACT OF PRE-SERVICE AND IN.

Commission on Higher Education Memorandum no. 41, series of 1998 "Continuing Professional Development for Teaching Staff in Higher Education Institutions, in accordance with the pertinent provisions of Republic Act No. 722, otherwise known as the "Higher Education Act of 1994."

Continuing Professional Development and the Philippine Qualifications Framework: A Way Forward to Mutual Recognition Arrangements: Library \& Information Science Book Chapter | IGI Global (igi-global.com).

Day, C. (1999). Developing teachers: The challenges of lifelong learning. London: Falmer Press.

Dewey, J. (1993). How We Think A Restatement of the Relation of Reflective Thinking to the Educative Process. Boston D. C. Heath.

De', R., Pandey, N., \& Pal, A. (2020). Impact of digital surge during Covid-19 pandemic: A viewpoint on research and practice. International journal of information management, 55, 102171.

Dilshad, Muhammad; Hussain, Bashir; Batool, Humera. (2019). Bulletin of Education and Research, v41 n3 p119-130.

Dove, M. G., \& Honigsfeld, A. (2018). Co-teaching for English learners: A guide to collaborative planning, instruction, assessment, and reflection. Thousand Oaks, CA: Corwin Press.

Flammer, A. (1995). Developmental analysis of control beliefs. In A. Bandura (Ed.), Self-efficacy in changing societies (pp. 69-115). Cambridge, UK Cambridge University Press.

Fielding, M, Bragg, S, Craig, J, Cunningham, I, Eraut, M, Gillinson, S, Horne, M, Robinson, C \& Thorp, J,. (2005). Factors Influencing the Transfer of Good Practice, DFES Research Report RR615, Falmer, University of Sussex.

Gaible, E. and Burns, M. (2005). Using Technology to Train Teachers: Appropriate Uses of ICT for Teacher Professional Development in Developing Countries. Washington: World Bank.

Guskey, T. R. (2002). Professional Development and Teacher Change. Teachers and Teaching, 8(3), 381-391. https://doi.org/10.1080/135406002100000512

Mariani, L. (1997). Teacher support and teacher challenge in promoting learner autonomy. Perspectives, 23(2).

Junaid Qadir and Ala Al-Fuqaha (September 2020). A Student Primer on How to Thrive in Engineering Education during and beyond COVID-19.

Kelchtermans, G. (2009). Who I am in how I teach is the message: Self-understanding, vulnerability and reflection. Teachers and Teaching: Theory and Practice, 15(2), 257-272.

King, H. (2004). Continuing professional development in higher education: What do academics do? Planet, 13(1), 26-29.

Knowles, M. S., Holton, E. F., \& Swanson, R. A. (2015). The adult learner. The definitive classic in adult education and human resource development (8 ed.). New York, NY: Routledge.

Levin, B. (2014). Professional development and the promotion of highly-effective teaching. Paper presented in 29th annual Emerging Issues Forum in North Carolina- USA on 10-11 February 2014.

Llangco, MO (2020). Considering "Turn-Digital” Qualitative Research Methods

Lupton, D. (2020). Doing fieldwork in a pandemic (crowd-sourced document).

https://docs.google.com/document/d/1clGjGABB2h2qbduTgfqribHmog9B6P0NvMgVuiHZCl8/ edit?ts=5e88ae0a\#.

Moustakas, C. (1994). Phenomenological research methods. Thousand Oaks, CA: Sage Publications, Inc.

Nordmeyer, J. (2015). Collaboration: Scaffolding student learning and teacher learning. EARCOS TriAnnual Journal. East Asia Council of Overseas Schools. 
International Journal of Management, Entrepreneurship, Social Science and Humanities (IJMESH), Vol. 4 (2), $129-145$

Lived Experiences of Educators Engaged in Continuing Professional Development in the New Normal: Insights from Seven Countries

Glen P. Cortezano; Rolando V. Maningas; Alberto D. Yazon; Lerma P. Buenvinida; Consorcia S. Tan; Victoria E. Tamban

Philipsen, B., Tondeur, J., McKenney, S., \& Zhu, C. (2019). Supporting teacher reflection during online professional development: A logic modelling approach. Technology, Pedagogy and Education, 28(2), 237- 253. DOI: 10.1080/1475939X.2019.16020777

Philipsen, B., Tondeur, J., Pareja Roblin, N., Vanslambrouck, S., \& Zhu, C. (2019). Improving teacher professional development for online and blended learning: A systematic meta-aggregative review. Educational Technology Research and Development, 67(5), 1145-1174. DOI: 10.1007/s11423-019-09645-8

Professional Regulation Commission Resolution No, 1032 Series of 2017, Implementing Rules and Regulations IRR of Republic Act no. 10912, known as the Continuing Professional Development (CPD) Act of 2016.

Organization for Economic Co-Operation and Development (OECD 2005). Teachers Matter: Attracting, Developing and Retaining Effective Teachers.

Rao, R. R. (2004). Method of teacher training. New Delhi: Discovery Publishing House.

Ross, J. A., \& Bruce, C. (2007). "Professional development effects on teacher efficacy; Results of randomized field trial". The Journal of Educational Research, 101 (1), 50-66.

Schleicher, A (ed), (2012). Preparing teachers and developing leaders for the 21st century: Lessons from around the world, Paris, Organisation for Economic Co-operation and Development.

Sessa, V, I., Kabacoff, R. I., Deal, J., \& Brown, H. (2007). Generational differences in leader values and leadership behaviors. Psychologist-Manager Journal, 10, 47-74

Seyoum, Yilfashewa, Online Submission, International Journal of Instruction v4 n2 p161-192 Jul 2011.

Seale, J. (2013). When digital capital is not enough: Reconsidering the digital lives of disabled university students. Learning, Media and Technology, 38(3), 256-269.

Seale, J., Georgeson, J., Mamas, C., \& Swain, J. (2015). Not the right kind of 'digital capital'? An examination of the complex relationship between disabled students, their technologies and higher education institutions. Computers and Education, 82, 118-128.

Taylor, R. (2013). Case-study research in context. Nurse Researcher, 20(4), 4-5.

United Nations Educational, Scientific and Cultural Organization (UNESCO, 2020)

Vescio, V, Ross, D \& Adams, A, 2008, A review of research on the impact of professional learning communities on teaching practice and student 